\title{
Application of Restriction Fragment Length Polymorphism Analysis to Simple and Rapid Genotyping of Bovine Viral Diarrhea Virus Strains Isolated in Japan
}

\author{
Yoshihisa SEKI ${ }^{1)}$, Yukio M. SEIMIYA ${ }^{1)}$, Masato MOTOKAWA ${ }^{1)}$, Gakuji YAEGASHI ${ }^{1)}$, \\ Makoto $\mathrm{NAGAI}^{2)}$ and Michiko HAYASHI ${ }^{2)}$ \\ ${ }^{1)}$ Iwate Prefecture Central Livestock Hygiene Service Center, 390-5 Sunagome, Takizawa-mura, Iwate 020-0173 and ${ }^{2)}$ Ishikawa Nanbu \\ Livestock Hygiene Service Center, Bo 324-2, Saida, Kanazawa-shi, Ishikawa 920-3101, Japan
}

(Received 8 August 2007/Accepted 10 December 2007)

\begin{abstract}
The E2 regions of 177 bovine viral diarrhea virus (BVDV) strains isolated in Japan between 1957 and 2006 were analyzed for genotyping. The strains were classified into 8 genotypes $(1 \mathrm{a}, 1 \mathrm{~b}, 1 \mathrm{c}, 1 \mathrm{~d}, 1 \mathrm{e}, 1 \mathrm{f}$, So and $2 \mathrm{a})$ based on the phylogenetic analysis. The restriction fragment length polymorphism (RFLP) analysis of the RT-PCR products using 6 selected enzymes (Apo I, Mly I, BstAP I, $P v u$ II, Ear I, EcoR V) disclosed the cutting patterns classified into 11 groups (I-XI), each of that consisted of strains belonging to a single genotype. Namely, groups-I and -II were composed by genotype-1a strains, groups-III and -IV by $1 \mathrm{~b}$ strains, and groups-V and -VI by $1 \mathrm{c}$ strains. Other groups-VII, -VIII, -IX, -X and -XI comprised genotypes-1d, -1e, -1f, -So and -2a strains, respectively. The results suggest that the RFLP analysis can simply and rapidly differentiate the 8 genotypes of BVDV strains. KEY WORDS: bovine viral diarrhea virus, genotyping, restriction fragment length polymorphism analysis.
\end{abstract}

J. Vet. Med. Sci. 70(4): 393-395, 2008

For efficient detection of herds including cattle persistently infected with bovine viral diarrhea virus (BVDV), the screening utilizing serum neutralizing tests, so-called spot tests, have been applied in several countries including Japan, Denmark and U.S.A. [9-11, 17, 20, 21]. The test is most exactly performed when the used indicator virus is antigenically similar to the strain prevalent in the population to be evaluated $[17,20]$. And the antigenicities are closely related to the genotypes $[8,16]$.

The phylogenetic analysis is the most reliable for genotyping but requires a great deal of labor and time as well as preparation of expensive instruments such as a sequencer. On the other hand, several PCR-based assays are used for the simple and rapid genotyping [2, 6, 7, 12, 13, 18, 23], although the range of genotypes classified by the assays is limited to only a few kinds. This report describes the results of the restriction fragment length polymorphism (RFLP) analysis applied to differentiate simply and rapidly the genotypes of BVDV strains prevalent in Japan.

A total of 177 BVDV strains were isolated from 12 Prefectures in Japan during the period from 1957 to 2006, 88 strains from Iwate Prefecture, 41 from Ishikawa Prefecture and the remaining 48 from 10 other Prefectures. Forty-one of 177 strains had been previously classified into genotypes1a, $-1 \mathrm{~b},-1 \mathrm{c},-1 \mathrm{e},-1 \mathrm{f}$, -So and -2a based on the analysis of E2 regions $[8,15]$. The 175 strains were isolated from diseased cattle and aborted fetuses. The 2 others were recovered from the imported fetal calf sera (FCS). The viruses were cloned by the limiting dilution method and propagated in bovine fetal muscular cells cultivated using the culture medium containing $5 \%$ horse serum. The RNA of the

\footnotetext{
* Correspondence to: Seki, Y., Iwate Prefecture Central Livestock Hygiene Service Center, 390-5 Sunagome, Takizawa-mura, Iwate 020-0173, Japan.

e-mail: yoshihisa-seki@pref.iwate.jp
}

cloned virus was extracted from the supernatant of the infected cells using the TRIzol-LS reagent (Invitrogen, U.S.A.) according to the manufacturer's instruction.

The sense primer $42 \mathrm{~F}$ (5'- ATG GRC CRG CYT TCC ARA TGG T -3', position in the BVDV SD-1 strain [3]: 2,826-2,847) and the antisense primer 6R (5'-TAG TTG AAG GTG CAT GCC GT-3', position in the strain: 3,3573,338 ) were prepared for the amplification of the partiallength E2 genes. The former primer was newly designed in this study and the latter was described previously [22]. The expected products were $532 \mathrm{bp}$ in size. RT-PCR was conducted using SuperScript One-Step RT-PCR with Platinum Taq (Invitrogen, U.S.A.) in a total volume of $50 \mu l$ containing $0.4 \mu \mathrm{M}$ of each primer and $1 \mu l$ of the extracted RNA. And the reaction mixtures were heated in a thermal cycler as follows: after cDNA synthesis at $50^{\circ} \mathrm{C}$ for $30 \mathrm{~min}$ and predenaturation at $94^{\circ} \mathrm{C}$ for $2 \mathrm{~min}, 35$ amplification cycles consisting of denaturation at $94^{\circ} \mathrm{C}$ for $1 \mathrm{~min}$, annealing at $55^{\circ} \mathrm{C}$ for $1 \mathrm{~min}$ and extension at $72^{\circ} \mathrm{C}$ for $1 \mathrm{~min}$ were performed with a final extension step at $72^{\circ} \mathrm{C}$ for $10 \mathrm{~min}$. Subsequently to the reaction, $5 \mu \mathrm{l}$ of each product was electrophoresed on a $2 \%$ agarose gel followed by staining with ethidium bromide.

The RT-PCR products were purified by Montage-PCR (Millipore, U.S.A.) and directly sequenced using the same primers and BigDye Terminator v1.1 Cycle Sequencing Kit (Applied Biosystems, U.S.A.) on Applied Biosystems 3130xl Genetic Analyzer (Applied Biosystems, U.S.A.). The determined sequences were aligned by the CLUSTAL $\mathrm{X}$ method [26] and the phylogenetic tree was constructed using the neighbor-joining method [19] along with the corresponding sequences of the following 18 reference strains: Oregon C24V (accession No. AF091605), Singer (L12455), NADL (M31182), FB1.91/1 (L38697), SD-1 (M96751), CP7 (U63479), New York-1 (AY027671), Osloss 
(M96687), Glen Innes (AF049226), Deer-NZ1 (AF144614), Bega (AF049221), SH9 (AF144616), 721 (AF144609), Deer-GB1 (AF144615), 11468 (AY734488), Giessen-1 (AF104030), 890 (U18059) and Gi-6 (AF144612). The reliability of the tree was evaluated by bootstrap analysis carried out on 1,000 replicates [5].

The cutting sites by the restriction endonucleases were investigated on the sequences of 177 strains using the MapDraw software (DNASTAR, U.S.A.), and 6 enzymes including Apo I, Mly I, BstAP I, Pvu II, Ear I and EcoR V (New England BioLabs, U.S.A.) were selected as candidates for genotyping. On RFLP analysis of 177 strains, $5 \mu l$ of RT-PCR products were added to $15 \mu l$ of the mixtures containing 10 units of an enzyme and reacted under the conditions recommended in the instructions. The digested fragments were visualized as mentioned above.

RT-PCR using 42F and 6R primers successfully amplified the products of the expected sizes from all 177 examined strains. The determined nucleotide sequences revealed that all RT-PCR products were 532 bp in size without deletion or insertion. On the phylogenetic tree based on the 490 nucleotides excluding positions annealed by the primers, 63 , 69 and 18 of 175 strains were classified into genotypes-1a, $1 \mathrm{~b}$ and $-1 \mathrm{c}$, and 4, 2, 2 and 17 strains into -1e, -1f, -So and $2 \mathrm{a}$, respectively. The 2 others from the imported FCS belonged to the genotype-1d. The bootstrap values of the clusters constructing each genotype were more than $94 \%$. The present reanalysis of 41 strains disclosed the identical genotypes with the previous results $[8,15]$.

The electrophoretic patterns observed on RFLP analysis were divided into 11 groups (I-XI) as shown in Table 1. Each group consisted of strains belonging to a single genotype. Namely, groups-I and -II were composed by genotype-1a strains, groups-III and -IV by $1 \mathrm{~b}$ strains, and
groups-V and -VI by 1c strains. Other groups-VII, -VIII, IX, -X and -XI comprised genotypes-1d, -1e, -1f, -So and 2a strains, respectively.

The RT-PCR products obtained from 37 (group-I) of 63 genotype-1a strains were digested into 265 and 267 bp in size by Apo I. Mly I also digested the products into 146 and $386 \mathrm{bp}$, with the exception that one strain (Nose) showed the digestion pattern of 106, 146 and $280 \mathrm{bp}$. None of the 4 other enzymes digested the products of this group. The 26 others (group-II) of genotype-1a strains showed the identical patterns with group-I strains by Apo I digestion. None of the 5 other enzymes digested the products, with the exception that one strain (IW20/97/NCP) were cut into 190 and 342 bp by Mly I and 2 strains (IW59/05/NCP, IS21NCP/00) into 174 and 358 bp by BstAP I.

The products of 69 genotype- $1 \mathrm{~b}$ strains were digested with 2 main patterns by Mly I and not by the 5 other enzymes. Namely, 22 strains (group-III) were cut into 252 and $280 \mathrm{bp}$, and the 47 others (group-IV) into 95, 185 and 252 bp with the exception of 2 strains (IS $3 \mathrm{NCP} / 95$, IS6NCP/95). The latter 2 strains showed the digestion patterns of $95,118,134$ and $185 \mathrm{bp}$.

Fourteen (group-V) of 18 genotype-1c strains were digested into 256 and 276 bp by BstAP I and not by the 5 other enzymes with the exception of the following 3 strains. Two strains (IW1/87/NCP, TC TA142/01) were cut into 265 and 267 bp by Apo I and 3 strains (IW1/87/NCP, IW4/89/ NCP, TC TA142/01) into 252 and 280 bp by Mly I. The 4 other genotype-1c strains (group-VI) were digested into 52 and 480 bp by $P v u$ II. Three strains (IW56/05/CP, IW56/05/ NCP, IW63/06/NCP) were also cut into 256 and 276 bp by BstAP I.

Two genotype-1d strains (group-VII) were digested into 262 and 270 bp by Ear I. One strain (OK1(CA)NCP/03)

Table 1. Grouping of 177 examined BVDV strains based on the RFLP patterns

\begin{tabular}{ccccccccc}
\hline \multirow{2}{*}{ Group } & \multirow{2}{*}{ Genotype } & No. of & \multicolumn{7}{c}{ The size (bp) of fragments generated by } \\
\cline { 4 - 9 } & & strains & Apo I & Mly I & BstAP I & $P v u$ II & Ear I & $E c o R$ V \\
\hline I & 1a & 37 & 265,267 & $146,386^{\text {a) }}$ & nd & nd & nd & nd \\
II & 1a & 26 & 265,267 & nd $^{\text {b) }}$ & nd & nd & nd & nd \\
III & 1b & 22 & nd & 252,280 & nd & nd & nd & nd \\
IV & 1b & 47 & nd & $95,185,252^{\text {d) }}$ & nd & nd & nd & nd \\
V & 1c & 14 & nd & nd & 256,276 & nd & nd & nd \\
VI & 1c & 4 & nd & nd & $256,276^{\mathrm{g})}$ & 52,480 & nd & nd \\
VII & 1d & 2 & nd & nd & nd & nd & 262,270 & nd \\
VIII & 1e & 4 & 265,267 & nd & nd & 218,314 & nd & nd \\
IX & 1f & 2 & nd & nd & nd & nd & nd & nd \\
X & So & 2 & nd & 252,280 & 256,276 & 175,357 & nd & nd \\
XI & 2a & 17 & nd & nd & nd & nd & nd & 167,365 \\
\hline
\end{tabular}

nd: Not digested.

a) Except Nose digested into 106, 146 and 280 bp for addition of one cutting site.

b) Except IW20/97/NCP digested into 190 and $342 \mathrm{bp}$.

c) Except IW59/05/NCP and IS21NCP/00 digested into 174 and $358 \mathrm{bp}$.

d) Except IS3NCP/95 and IS6NCP/95 digested into 95, 118, 134 and $185 \mathrm{bp}$.

e) Except IW1/87/NCP and TC TA142/01 digested into 265 and $267 \mathrm{bp}$.

f) Except IW1/87/NCP, IW4/89/NCP and TC TA142/01 digested into 252 and $280 \mathrm{bp}$.

g) Except Okazaki/01/04 not digested for loss of one cutting site.

h) Except $\mathrm{OK} 1(\mathrm{CA}) \mathrm{NCP} / 03$ digested into 174 and $358 \mathrm{bp}$. 
was also cut into 174 and 358 bp by BstAP I. None of the 4 other enzymes digested the products. Four genotype-1e strains (group-VIII) disclosed the patterns of 265 and $267 \mathrm{bp}$ by $A p o$ I as well as 218 and 314 bp by $P v u$ II. Two genotype-1f strains (group-IX) had no cutting sites of the 6 enzymes. Two genotype-So strains (group-X) disclosed the patterns of 252 and 280 bp by Mly I, 256 and 276 bp by BstAP I and 175 and 357 bp by $P v u$ II. Seventeen genotype2a strains (group-XI) were cut into 167 and 365 bp only by EcoR V.

Previous phylogenetic analysis of E2 genes has often been accomplished based on the RT-PCR and sequencing using plural primer sets $[1,25]$, since the regions are considerably variable $[3,4]$. In this study the RT-PCR using a single primer set consisting of the newly designed $42 \mathrm{~F}$ and previously reported $6 \mathrm{R}$ [22] successfully amplified the regions of all 177 examined strains, which were subsequently divided into 8 genotypes based on the nucleotide sequences determined by the primer set. On the phylogenetic tree, the clusters constructing each genotype were supported by the bootstrap values of more than $94 \%$ and reanalysis of 41 strains disclosed the identical genotypes with previous results $[8,15]$. The subjected E2 regions contained the 420 nucleotides that had often been analyzed phylogenetically in Japan $[15,24]$. These results suggest that the present primer set could contribute to the phylogenetic analysis of E2 genes.

Based on the phylogenetic analysis, the examined strains were frequently divided into genotypes- $1 \mathrm{a}$ and $-1 \mathrm{~b}$, occasionally genotypes- $1 \mathrm{c}$ and $-2 \mathrm{a}$ and rarely $-1 \mathrm{e},-1 \mathrm{f}$ and - So, and included 2 genotype-1d strains from the imported FCS. The obtained results appear to suggest that the examined strains could be representative of Japanese isolates from the view of the kinds and frequency of the detected genotypes $[8,14-16,24]$.

The RFLP patterns obtained from 177 strains using 6 selected enzymes were divided into 11 groups (I-XI). The identical cutting patterns were found in most strains within each group and the different patterns were observed in a few strains. However, the patterns of the latter minor strains were differentiated from those of the strains within the other groups when analyzed by the present 6 enzymes. Each group consisted of strains belonging to a single genotype, such as genotype-1a strains in groups-I and -II, 1b strains in groups-III and -IV, and 1c strains in groups-V and -VI. The differences in the cutting patterns among the 11 groups were easily visualized by the present electrophoresis. The results suggest that the present RFLP analysis could simply and rapidly differentiate compared with the phylogenetic analysis the 8 genotypes of strains that have so far been isolated in Japan, although no enough strains to evaluate in number were examined on several genotypes.

ACKNOWLEDGMENTS. We thank Shimane Prefectural Domestic Livestock Disease Identification Office (Mr. N. Kaji), Livestock Hygiene Service Centers of Tochigi (Ms.
K. Iwane), Aichi (Mr. M. Kuwabara and Ms. Y. Maeda), Gifu (Mr. Y. Tanahashi), Okayama (Dr. T. Fukutomi), Fukuoka (Mr. K. Gotou) and Kumamoto (Mr. R. Kono) Prefectures and Hokkaido Government for kindly providing the BVDV isolates. We also wish to thank National Institute of Animal Health for supplying the KS86-1CP and KS86$1 \mathrm{NCP}$ strains and Iwate Biotechnology Research Center (Dr. M. Nishihara) for cooperation with the sequence analysis.

\section{REFERENCES}

1. Becher, P., Orlich, M., Kosmidou, A., Konig, M., Baroth, M. and Thiel, H.-J. 1999. Virology 262: 64-71.

2. Bhudevi, B. and Weinstock, D. 2001. Vet. Microbiol. 83: 1-10.

3. Deng, R. and Brock, K. V. 1992. Virology 191: 867-879.

4. Donis, R. O. 1995. Vet. Clin. North Am. Food Anim. Pract. 11: 393-423.

5. Felsenstein, J. 1985. Evolution 39: 783-791.

6. Gilbert, S. A., Burton, K. M., Prins, S. E. and Deregt, D. 1999. J. Clin. Microbiol. 37: 2020-2023.

7. Harpin, S., Mehdy Elahi, S., Cornaglia, E., Yolken, R. H. and Elazhary, Y. 1995. Arch. Virol. 140: 1285-1290.

8. Hayashi, M., Murakami, T., Takai, H., Nagai, M., Yamaguchi, T., Funaki, O. and Akashi, H. 2006. J. Jpn. Vet. Med. Assoc. 59: 320-324 (in Japanese with English summary).

9. Houe, H. 1992. Res. Vet. Sci. 53: 320-323.

10. Houe, H. 1999. Vet. Microbiol. 64: 89-107.

11. Houe, H., Baker, J. C., Maes, R. K., Ruegg, P. L. and Lloyd, J. W. 1995. J. Vet. Diagn. Invest. 7: 327-332.

12. Letellier, C. and Kerkhofs, P. 2003. J. Virol. Methods 114: 2127.

13. Letellier, C., Kerkhofs, P., Wellemans, G. and Vanopdenbosch, E. 1999. Vet. Microbiol. 64: 155-167.

14. Matsuno, K., Sakoda, Y., Kameyama, K., Tamai, K., Ito, A. and Kida, H. 2007. J. Vet. Med. Sci. 69: 515-520.

15. Nagai, M., Hayashi, M., Sugita, S., Sakoda, Y., Mori, M., Murakami, T., Ozawa, T., Yamada, N. and Akashi, H. 2004. Virus Res. 99: 103-113.

16. Nagai, M., Ito, T., Sugita, S., Genno, A., Takeuchi, K., Ozawa, T., Sakoda, Y., Nishimori, T., Takamura, K. and Akashi, H. 2001. Arch. Virol. 146: 685-696.

17. Pillars, R. B. and Grooms, D. L. 2002. Am. J. Vet. Res. 63: 499-505.

18. Ridpath, J. F. and Bolin, S. R. 1998. Mol. Cell. Probes 12: 101-106.

19. Saitou, N. and Nei, M. 1987. Mol. Biol. Evol. 4: 406-425.

20. Seki, Y., Seimiya, Y. M., Motokawa, M., Miyazaki, H., Konno, M. and Yaegashi, G. 2007. J. Vet. Med. Sci. 69: 10871089.

21. Seki, Y., Seimiya, Y. M., Yaegashi, G. and Sato, C. 2006. J. Vet. Med. Sci. 68: 255-258.

22. Sentsui, H., Nishimori, T., Kirisawa, R. and Morooka, A. 2001. Arch. Virol. 146: 993-1006.

23. Sullivan, D. G. and Akkina, R. K. 1995. Virus Res. 38: 231239.

24. Tajima, M. 2004. Vet. Microbiol. 99: 131-138.

25. Tajima, M., Frey, H.-R., Yamato, O., Maede, Y., Moennig, V., Scholz, H. and Greiser-Wilke, I. 2001. Virus Res. 76: 31-42.

26. Thompson, J. D., Gibson, T. J., Plewniak, F., Jeanmougin, F. and Higgins, D. G. 1997. Nucleic Acids Res. 25: 4876-4882. 